\title{
MARKETING MIX EFFECT ON CUSTOMER SATISFACTION ON THE TOURISM IN TOMOHON CITY
}

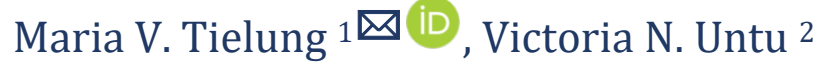 \\ 1,2 Department of Management, Faculty of Economic and Business Sam Ratulangi University, \\ Indonesia
}

DOI: https://doi.org/10.29121/granthaalayah.v9.i1.2021.2870

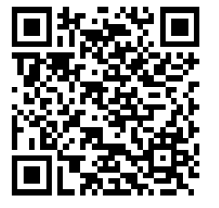

Article Type: Research Article

Article Citation: Maria V. Tielung, and Victoria N. Untu. (2021). MARKETING MIX EFFECT ON CUSTOMER SATISFACTION ON THE TOURISM IN TOMOHON CITY. International Journal of Research GRANTHAALAYAH, 9(1), 25-36. https://doi.org/10.29121/granthaa layah.v9.i1.2021.2870

Received Date: 25 December 2020

Accepted Date: 22 January 2021

Keywords:

Marketing Mix

Customer Satisfaction

\section{ABSTRACT}

Motivation/Background: Consumer satisfaction is very important for a tourist spot, because it determines the ability and level of profit it can achieve. Because it is necessary to pay attention to things that have the potential to affect consumer satisfaction, including the Marketing Mix. This study discusses the aspects of the marketing mix that affect consumer satisfaction at tourist attractions in the city of Tomohon. The aim is to determine the effect of the Marketing Mix on Customer Satisfaction. Marketing Mix (Marketing Mix) is a set of marketing tools that companies use to achieve goals in target markets. Marketing Mix includes variable Product (Product), Price (Price), Place (Place) and Promotion (Promotion). Consumer satisfaction is the feeling of pleasure or disappointment of a customer that arises after comparing perceptions of the performance of a product and its expectations.

Method: In this study, the data collection techniques used were observation, interviews and a list of questions given to consumers or guests on the object under study. The variables measured are the factors of the marketing mix including product (X1), price (X2), place (X3) and promotion (X4), and customer satisfaction (Y). The analytical method used is Multiple Linear Regression Analysis.

Results: From the analysis results obtained the value of the coefficient

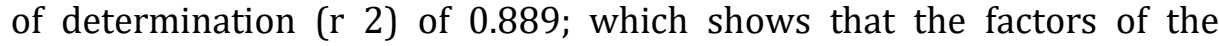
Marketing Mix have a contribution or proportion of the contribution to the variation (fluctuation) of Consumer Satisfaction by $88.9 \%$, while the remaining $11.1 \%$ is explained by other factors.

Conclusions: From the research results, the value of the Correlation Coefficient ( $\mathrm{r}$ ) is $0.943(94.3 \%)$ or close to $1(100 \%)$, which indicates that there is a very close and positive relationship between the Marketing Mix and the Consumer Satisfaction.

\section{INTRODUCTION}

\subsection{BACKGROUND}

Nowadays, the construction of tourist attractions is growing rapidly, whether it is the construction of a new place or the provision of a new place in an existing location. With the advancement of

(C) 2021 The Author(s). This is an open access article distributed under the terms of the Creative Commons Attribution License, which permits unrestricted use, distribution, and reproduction in any medium, provided the original author and source are credited. 
technology and the flow of information that spreads rapidly and changes that occur in economic, demographic and socio-cultural conditions, many influence consumer behaviors in choosing and making buyers' decisions. Therefore, marketers must always change in order to take advantage of the opportunities that exist in the market.

One of the company's steps in making business effective is to use a marketing mix planning (marketing mix). There are four main elements, namely what are commonly referred to as four (product, price, place, promotion). The four main elements in the marketing mix or the so-called 4P are the variables that are studied in this study.

Increasing competition in the tourism industry, as well as a decrease in the average rate of visits or tourist arrivals are problems that must be considered by every tourist hotel in the city of Tomohon. Tomohon City was chosen as the object of research because it is one of the locations that is in great demand by consumers, in this case both domestic and foreign tourists.

Marketing Mix is a major service marketing tool to achieve company goals. The marketing mix is a function that has great contact with the external environment. Marketing vessels play an important role as part of the company's strategy and policies to achieve consumer satisfaction which in turn is expected to increase customer satisfaction.

\subsection{FORMULATION OF THE PROBLEM}

Based on the background of the problem as stated earlier, the formulation of the problem can be drawn as follows:

" How is the influence of the marketing mix (including product, price, place and promotion) on consumer satisfaction at tourist attractions in the city of Tomohon?".

\section{CONCEPTUAL FRAMEWORK}

\subsection{MARKETING STRATEGY}

To achieve the desired goals, a company must establish corporate strategies so that the planned goals can be achieved. Therefore, strategy is very important for a company, including in terms of marketing its products.

According to Walker and Larrecche (2013), Marketing Strategy is: "The fundamental pattern of current and planned objectives, mobilization of resources and the interaction of the organization with competing markets and other environmental factors ".

The main focus of the marketing strategy is to allocate and coordinate resources in marketing activities, to achieve its goals within a specific market product. Peter and Olson explain that Marketing Strategy is: "A set of stimulants that are placed in the customer's environment and designed to stimulate influence, understanding and behavior. These stimuli include products, brands, packaging, advertisements, market coupons, credit cards, price lists, communications from salespeople and other things".

Kotler (2013) defines Marketing Strategy as: "The basic principles underlying Marketing Management to achieve business and marketing in a target market ".

To arrive at these goals, we need a strategy that shows the way how the achievement of these goals. In doing so, companies can use a tool that is " Marketing Mix " as a concept in developing a Marketing Strategy.

\subsection{MARKETING MIX}

Setyawan (2011) states that the influence of the elements of the Marketing Mix on the perception and behavior of acceptors (customers) is: " understanding the needs of acceptors (customers) by always striving to provide the best service ". This is important and must be maintained in line with the company's program for the commodities to be sold, so it requires a current marketing concept. This concept is a human activity in the exchange process which is directed to satisfy the needs of consumers (acceptors).

The success of providing acceptor decisions in company programs can realize hopes of increasing awareness, role and community responsibility for institutionalization and culture, further expectations about the success of corporate marketing are more influenced by the implementation of mix elements and acceptor responses in the form of perceptions and behavior of the company. All of the proposed hypotheses were not rejected. This shows that the 
proposed concept turns out to be a unitary independent variable that cannot be separated in influencing the dependent variable with the support of a fairly good influence.

According to Kartajaya (2011), Marketing Mix is a process of integrating offer, logistics and communication. The offer from the company which consists of products and prices must be well integrated with logistics and communications, in order to create a strong marketing in the market.

According to Stanton (2010), Marketing Mix is a term used to describe the combination of the main elements that make up the core of the marketing system in an organization. The Marketing Mix that is carried out must be adjusted to the situation and conditions of the company. Besides, Marketing Mix is a combination of factors that can be controlled company to facilitate purchasing decisions (buying decision).

\subsection{MARKETING MIX ELEMENTS}

According to Husnan and Suwarsono (2011), there are many differences of opinion about the types and number of variables in the Marketing Mix, although it can be said that overall, there are no contradictory differences. These differences are generally due to developments and advancements accompanied by changes experienced in the field of marketing. Some of the opinions on the division of elements of the Marketing Mix are

1) Distinguishing the Marketing Mix in two main variable components, namely:

a) What will be handed over to consumers.

In this case include:

- Product quality.

- Wrapping.

- Brand.

- Price.

b) The tools and methods used.

In this case include:

- Distribution Channels.

- Personal Selling.

- Sales Promotion.

- Publications

2) Distinguishing the marketing mix into three main variable components, namely:

- Good and Service Mix.

- Distribution Mix.

- Communication Mix.

c) Distinguishing the Marketing Mix in the four main variable components, or commonly referred to as "4-P", namely:

- Products (product).

- Distribution channels (place).

- Price (Price).

- Promotion (Promotion).

In this research, the last marketing mix differentiation is the "4-P" concept used. Thus, because the use of the Marketing Mix is to influence demand for products, if it is manifested in the equation, it is as follows;

Demand $=\mathrm{f}(4 \mathrm{P})$.

According to Stanton (2012), Marketing Mix is a term used to describe the combination of the four major elements that form the core of an organization's marketing system, which is often referred to as the "four p`s”, namely:

- Product Strategy.

- Pricing Strategy.

- Distribution or Distribution Strategy.

- Promotion Strategy.

According to Samuel (2011), the existence of the Marketing Mix as factors that play a role in creating consumer satisfaction can continue to grow in line with changes in consumer perceptions. Where the Marketing Mix referred 
to in the 4Ps are Product, Price, Promotion, Place, which can then be added with new elements such as Participant, Process and Physical Evidence.

\subsection{PRODUCT}

Policy regarding products or services includes the number of goods / services the company will offer, special services the company offers to support the sale of goods and services, and the form of goods or services offered. Product is the most important element. because with this the company strives to meet the " needs and wants " of consumers. However, the decision does not stand alone, because the product / service is closely related to the chosen target market.

The following is a product definition according to several experts:

Understanding the product according to Kotler (2012):

"A product is an activity that can be offered in the market for attention, possession, use or consumption so as to satisfy a want or need ".

Kotler explained that the level of marketing a product consists of basically four stages:

1) The introduction phase (Introduction)

A period of slow sales growth when a product is introduced to the market. Profit has not been earned at this stage due to the high cost of introducing the product.

2) Growth stage (Growth)

A period of rapid market growth and significant increase in profits.

3) Maturity stage (Marturity)

A period of weak sales growth because the product has gained recognition from most potential buyers, profits have stabilized or decreased due to increased marketing spending to counter product competition.

4) Decline stage

The period when sales show a decrease in profit is emotional.

Planning products and services (product and service planning) includes test marketing, product positioning and brand, warranty plan, the packaging, the choice of products, product features, product model, product quality, eliminate old products, and providing customer service.

\subsection{PRICE}

Every company always pursues profit for sustainable production. The profit earned is determined by the pricing offered. The price of a product or service is also determined by the amount of sacrifice made to produce the service, and the profit or profit expected. Therefore, determining the product price of a company is an important issue, because it can affect the life and death of the company. Price policy is very crucial in the decision to offer a product or service to the market.

Consumer purchasing decisions are not based solely on price. But also, on other factors such as product quality and trust in the company. It is important for the company to set the most appropriate price, in the sense that it can provide benefits for the short term and for the long term and can retain consumers.

According to Umar (2011), the definition of price is: "the amount of value that consumers exchange for the benefit of owning or using a product or service, whose value is determined by the buyer and seller through bargaining or set by the seller for the same price for all buyers ".

In pricing, companies must assess from short-term and long-term perspectives, among others by evaluating price-cutting policies (discounts), rules for granting credit and payment methods, conditions and terms of sale, markups and costs, momentum (timing) of issuing new price lists. and pay attention to changes in competitors' prices.

According to Kotler (2012), in the end it is the consumer who will determine the right price of a product. When setting prices, companies must also pay attention to consumer perceptions of prices, and how these perceptions influence consumer purchasing decisions. 


\subsection{DISTRIBUTION CHANNELS (PLACE)}

What should not be ignored in the activity steps to smooth the flow of goods / services is to choose a Channel of Distribution. The problem of selecting distribution channels is a problem that affects marketing, because mistakes in choosing can hinder and even jam efforts to distribute products / services from producers to consumers.

Place (place) or known by the name of Distribution Channels, a marketing agency that is traversed by a product distributing goods from producers to consumers. In order for the product to spread quickly to consumers and to reach the marketing area, a company must establish the use of Distribution Channels.

According to Kotler and Armstrong (2001: 49), the company's distribution channel decisions directly influence other marketing decisions. Management must make decisions Distribution Channels carefully, by linking current needs as well as the possibility of future sales environment will come. The distribution channel that is closest to the final consumer will determine the consumer's choice of the product.

Definition of Distribution Channels according to Kotler (2012):

" Distribution Channels are associations of companies and individuals who take over rights, or assist in the transfer of rights to goods or services as long as these goods or services move from producers to consumers ".

Distribution policies include, among others, the selection of Distribution Channels, distribution coverage, sales territories, location of retail stores, wholesalers, retailers, stock levels and locations, warehousing, and means of transportation. The distribution channels available include marketing organizations that act as intermediaries, wholesalers, retailers, brokers, facilitators, agents, vendors or distributors.

\subsection{PROMOTION}

The promotion aspect relates to various efforts to provide information to the market about the products and services sold, where and when. According to Kotler (2012), Promotion activities include:

\section{Advertising}

Advertising is used to build a long-term image for a product, an efficient way to reach a geographically dispersed range of buyers at a lower cost, and to drive sales faster such as cheap hotel rate advertisements on weekends. Decisions related to advertising include determining the form of news advertisements and the selection of such media (newspapers, magazines, television, radio, internet and so on). Advertising is sometimes accompanied by leaflets or brochures that are distributed to people or can be via direct mail.

\section{Personal Selling}

Personal Selling is the interaction between individuals, face to face with the aim of creating, repairing, controlling or maintaining mutually beneficial exchange relationships. Personal Selling activities include withdrawal, the selection of a seller salesman, training, compensation and supervision. Personal Selling requires providing training to salespeople carefully, for example regarding how to look, the attitude in welcoming and responding to consumer needs, providing information, and how to resolve their doubts and complaints.

\section{Sales Promotion}

Sales promotion is an activity to introduce a product through an exhibition, demonstration, sample demonstration and so on. Sales promotion consists of a diverse set of incentive tools, most of them short term, designed to encourage the faster and larger purchase of a particular product and service. Sales promotions can take the form of in-store demonstrations, coupons, grand gifts, and visits to famous people.

\section{Publicity and Public Relations (Publicity and Public Relations)}

Publicity is a marketing communication in the form of news, where messages given to consumers can be dramatized to attract high trust. Publicity can be done easily for marketers if they have something interesting to say

\section{Direct Marketing}

Direct offering is an interactive marketing system that uses one or more advertising media for measurable responses or transactions at any location.

\subsection{CUSTOMER SATISFACTION}

Today many companies, including service companies, state that the company's goal is to satisfy customers. The more advanced and developing a society, the more types and qualities of human needs increase. This is reflected in 
the increasing demands of society (consumers) to obtain good and maximum service. Customer satisfaction is no longer just the quality or quality of goods or services provided, but shifts to how customers or consumers get satisfactory treatment.

Kotler (2012) defines Customer Satisfaction as:

"A person`s feeling of pleasure or disappointment resulting from comparing a product`s received performance (our outcome) in relations to the person`s expectation ".

Which means:

"The feeling of pleasure or disappointment of a customer that arises after comparing the perception of the performance (results) of a product and its expectations ".

According to Kotler (2002) there are several benefits of customer satisfaction, namely: The relationship between the company and its customers is harmonious.

1) Provides a sound basis for purchasing money.

2) Can encourage the creation of customer loyality.

3) Forms favorable word of mouth recommendations.

4) The company's reputation is good in the eyes of customers.

5) The profit earned can increase.

According to Mowen and Minor (2010), Consumer Satisfaction is:

"The overall attitude shown by consumers on goods or services after they obtain and use them ".

\section{MATERIALS AND METHODS}

\subsection{TYPES OF RESEARCH}

This research is classified as a quantitative descriptive study, which means that in analyzing data using numerical formulas or mathematical models.

\subsection{LOCATION AND TIME OF RESEARCH}

This research was conducted at tourist attractions in the city of Tomohon

\subsection{DATA ANALYSIS}

This research uses the method of analysis method used in this research is Multiple Linear Regression Analysis, equipped with Partial Hypothesis Testing with the t test and Simultaneously with the F test, the calculation of the coefficient of determination and the correlation coefficient.

\subsection{POPULATION AND SAMPLE}

The population of this study are visitors to tourist attractions in the city of Tomohon. In taking the sample, random sampling technique was used and obtained 70 respondents.

\section{RESULT AND DISCUSSION}

\subsection{HISTORY OF TOMOHON CITY}

Tomohon City has been written in several historical records since ancient times. One of them is in the ethnographic work of Pastor N. Graafland who when on January 14, 1894 on the ship Queen Elisabeth, he wrote about a country called Tomohon which he visited in around 1850. The development of civilization and the dynamics of development and social organization from year to year make Tomohon as one of the sub-district capitals in Minahasa Regency. 
The early decades of the 2000s, the people in several parts of the Minahasa district inspired and aspired to the strategic environment, both internally and externally, to carry out regional expansion. The blowing winds of reform and the implementation of regional autonomy policies have further accelerated the process of accommodating people's aspirations for the expansion of the region concerned. Through a long juridical process and careful consideration in the context of accelerating national development for the welfare of the wider community, the Minahasa District government and the Minahasa District Representative Council recommended the community's aspirations for the establishment of South Minahasa Regency, Tomohon City, and North Minahasa Regency which are supported by government of North Sulawesi Province. The central government stipulated the formation of South Minahasa Regency and Tomohon City with the issuance of Law Number 10 of 2003 dated January 27, 2003.The formation of the Tomohon City legislative body as a result of the 2004 General Election resulted in the Regional Regulation of Tomohon City Number 22 of 2005 concerning Regional Symbols and Regional Regulations Tomohon City Number 29 of 2005 concerning Tomohon City Anniversary. The City of Tomohon was inaugurated by the Minister of Home Affairs Harry Sabarno on behalf of the President of the Republic of Indonesia on August 4, 2003.

Tomohon City is one of the areas in North Sulawesi, which can be reached by using land transportation from the capital city of North Sulawesi Province, Manado $+25 \mathrm{Km}$. If from Sam Ratulangi International Airport $+34 \mathrm{Km}$. The location of Tomohon City Area is surrounded by the Minahasa Regency Area; namely in the north bordering Pineleng and Tombulu sub-districts (Kab. Minahasa.In the south bordering Sonder and Remboken subdistricts (Kab.Minahasa) in the west with sub-district Tombariri (Kab.Minahasa) and in the east bordering Tondano District (Kab. Minahasa)) and Airmadidi sub-districts (North Minahasa regency). Meanwhile, districts / cities adjacent to Tomohon City are South Minahasa District (West) Manado City (North) Minahasa Regency (East) and Southeast Minahasa Regency (South)

Tomohon City is located in a mountainous area located at 0o 18 '51 "North Latitude and 1240 49' 40" East Longitude, has an area of $147.21 \mathrm{Km} 2$ and is at an altitude of $400-1500 \mathrm{~cm}$ above sea level with a temperature range of 180C - 300C.

There are three mountains, namely Mount Lokon (1,579,6m asl), Mount Tampusu, 1,474 m asl) and Mahawu (1,331 $\mathrm{m}$ asl). Several rivers such as the Ranowangko River, Sapa River, Sinambey River and 32 springs are scattered. In addition, there are two lakes, namely Lake Linow and Lake Pangolombian.

The population development in Tomohon City is quite controlled, this can be seen in 2011 as many as 95,575 people and the largest number were in North Tomohon Subdistrict, 27,045, while the smallest was in East Tomohon Subdistrict, amounting to 10,987. Furthermore, in 2014 it increased to 101,665 people and the most lived in North Tomohon sub-district with 29,360 people, while the smallest was in East Tomohon sub-district with 11,460 people. Until 2015, the population of Tomohon has reached 103,506.

Tomohon City is a city in North Sulawesi Province which was once a sub-district in the Minahasa district. Now, this city is transformed into a beautiful city and has various tourist destinations that are continuously being developed. Industrial center in the town of Tomohon is also very popular, the city famous for home industries stage.

Therefore, if you are visiting Tomohon Flower City, don't forget to explore the extraordinary tourist spots in Tomohon City.

\subsection{DISCUSSIONS}

\subsubsection{GENERAL DESCRIPTION OF RESEARCH RESPONDENTS}

To be able to know more comprehensively the effect of the Marketing Mix on Customer Satisfaction at tourist attractions in the city of Tomohon, this study took a sample of 70 people as respondents. Thus, the data collected is expected to represent the entire population so that it can produce better answers. The research was conducted in several tourist attractions that exist in Tomohon, with the group the respondents into categories based on gender, age, and occupation. Based on the data obtained, the authors describe the following general description of the respondents. 


\subsubsection{COMPOSITION OF RESPONDENTS BY GENDER}

In this study, the state of gender needs to be known to get a more complete picture of respondents' preferences for their tastes and satisfaction with the variables studied. The condition of respondents according to gender is presented in Table 5.1:

Table 4 .1: Composition of Research Respondents Based on Gender at tourist attractions in Tomohon City, 2020.

\begin{tabular}{|c|c|c|c|}
\hline No & Type Sex & Amount Respondents & Percentage (\%) \\
\hline 1 & Men & 27 & $38.57 \%$ \\
\hline 2 & Woman & 43 & $61.43 \%$ \\
\hline & TOTAL & 70 & $100 \%$ \\
\hline
\end{tabular}

Source: Results of Questionnaire Data, 2020.

From Table 5 .1. It can be seen that the respondents we met in this study were mostly women with a ratio nearly 2 times the number of the sample of men. This data generally indicates that the majority of visitors to tourist attractions are women.

\subsubsection{COMPOSITION OF RESPONDENTS BY AGE}

In this study, it is necessary to know the condition of age to get a more complete picture of respondents' preferences for their tastes and their satisfaction with the variables studied. The condition of the respondents according to age is presented in Table 5.2. the following:

Table 4 .2: Composition of Research Respondents based on Age at tourist attractions in Tomohon City, 2020.

\begin{tabular}{|c|c|c|c|}
\hline No & Age & Amount Respondents & Percentage (\%) \\
\hline 1 & $<20$ years & 2 & $2.86 \%$ \\
\hline 2 & $20-30$ years & 29 & $41.43 \%$ \\
\hline 3 & $30-40$ years & 13 & $18.57 \%$ \\
\hline 4 & $40-50$ years & 26 & $37.14 \%$ \\
\hline & TOTAL & 70 & $100 \%$ \\
\hline
\end{tabular}

Source: Results of Questionnaire Data, 2020.

From Table 5 .2. at the top, it can be seen that the respondent was greatest in the age of 20-30 years with a difference that is not too great with the respondents at the age of 40-50 years. While the respondents in the age under 20 years old is the youngest respondents. From the above comparisons, in general it can be said that the majority of visitors to tourist attractions in Tomohon City consist of adults.

\subsubsection{COMPOSITION OF RESPONDENTS BY TYPE OF WORK.}

In this study, the condition of work needs to be known to get a more complete picture of respondents' preferences for their tastes and satisfaction with the variables studied. The respondent's condition according to the type of work is presented in Table 5.3. the following:

Table 4 .3. Composition of Research Respondents Based on Types of Work at tourist attractions in Tomohon City, 2020.

\begin{tabular}{|c|c|c|c|}
\hline No & Profession & Amount Respondents & Percentage (\%) \\
\hline 1 & College student & 11 & $15.72 \%$ \\
\hline 2 & Civil servants & 33 & $47.14 \%$ \\
\hline 3 & General employees & 26 & $37.14 \%$ \\
\hline
\end{tabular}


Maria V. Tielung, and Victoria N. Untu

\begin{tabular}{|c|c|c|c|}
\hline & TOTAL & 70 & $100 \%$ \\
\hline
\end{tabular}

Source: Processed Questionnaire Data, 2020.

From Table 5 .3. it can be seen that most respondents are those that have a job as a civil servant with almost half of the sample. The data generally indicates that visitors to the tourist places in the city of Tomohon to now comprise the majority of civil servants.

In addition, respondents who work as civil servants and private employees account for almost $84 \%$ of the total sample. The data also indicates that at tourist attractions in Tomohon City, most of the guests who come are workers or professionals, who come to visit because they are related to official needs or for personal purposes such as vacationing. To measure the effect of the Marketing Mix in the form of Products, Prices, Places and Promotions on Customer Satisfaction, this study uses a list of questions (questionnaires) that are distributed to respondents.

\subsection{DISCUSSION}

The results of this study are basically interrelated and in line with the conclusions of previous research results that have been stated in the literature review in Chapter I. Where the marketing mix factors basically have a relationship with consumer satisfaction. In other words, the results of this study complement the conclusions obtained in previous studies which state that Marketing Mix is an important thing that can increase Customer Satisfaction in a company.

it can be said that the results of this study support and strengthen the results of previous studies and confirm and answer the hypotheses that have been put forward. Namely that the Marketing Mix can affect Customer Satisfaction. Or in other words, the Marketing Mix factors have a strong, positive and direct relationship with Customer Satisfaction.

Based on the results of the analysis and discussion of the interpretation of the research results above, it can be said that the Marketing Mix variables in the form of Product, Price, Place and Promotion variables together or simultaneously (simultaneously) have a relationship and influence on the Consumer Satisfaction variable (Y). In addition, separately or individually (partially), either the Product variable $\left(\mathrm{X}_{1)}\right.$, the Price variable $\left(\mathrm{X}_{2)}\right.$, the Place variable $\left(\mathrm{X}_{3)}\right.$ and the Promotion variable $\left(\mathrm{X}_{4)}\right.$ ) also have a relationship or influence on the Consumer Satisfaction variable. (Y). Where the form of the relationship between each Marketing Mix variable and the Consumer Satisfaction variable is described in the following discussion of the results.

\subsubsection{EFFECT OF PRODUCT VARIABLES $\left(X_{1)}\right.$ ON CUSTOMER SATISFACTION (Y)}

The results of this research, through partial hypothesis testing, prove that the product variable has a strong relationship and a positive influence with the consumer satisfaction variable. The results of hypothesis testing simultaneously show that the product variable together with other marketing mix can affect customer satisfaction.

The magnitude of the influence of the Product variable $\left(\mathrm{X}_{1)}\right.$ on the Consumer Satisfaction variable (Y) is obtained from the value of the Regression Coefficient of 0.17 . This means that if the Product variable $\left(\mathrm{X}_{1)}\right.$ increases (: because the sign is positive) by 1 score, it is expected that the Consumer Satisfaction variable (Y) will increase by 0.147 scores, Ceteris Paribus (other factors do not change or remain).

The results above indicate that the product variable has a strong and positive influence relationship with customer satisfaction at tourist attractions in the city of Tomohon. Which this shows that every change that occurs in the Product variable, will also result in changes in Customer Satisfaction in the same direction of change.

it can be said that every effort made by the company to improve the quality of the product variable will significantly increase the existing consumer satisfaction. For that, company management needs to develop a marketing strategy that can encourage increased quality of the company's product variables. Because by doing so, customer satisfaction or visitors to tourist attractions in Tomohon City can be increased.

\subsubsection{THE EFFECT OF PRICE VARIABLES $\left(X_{2)}\right.$ ON CUSTOMER SATISFACTION (Y)}

The results of the research, through partial hypothesis testing, prove that the price variable has a strong relationship and a positive influence with the consumer satisfaction variable. The results of testing the hypothesis 
simultaneously show that the price variable together with other marketing mix can affect customer satisfaction. The magnitude of the influence of the price variable $\left(\mathrm{X}_{2)}\right.$ on the Customer Satisfaction variable $(\mathrm{Y})$ is obtained from the value of the Regression Coefficient of 0.239. This means that if the quality of the Price $\left(\mathrm{X}_{2)}\right.$ variable setting increases (: because the sign is positive) by 1 score, it is expected that the Consumer Satisfaction variable (Y) will increase by 0.239 score, Ceteris Paribus (other factors do not change or remain).

The results above indicate that the price variable has a strong and positive influence relationship with customer satisfaction at tourist attractions in the city of Tomohon. Which this shows that any changes that occur in the price variable, will also result in changes in Customer Satisfaction in the same direction of change. Thus, it can be said that every effort the company makes to improve the quality of the price variable will significantly increase the existing consumer satisfaction. For that, company management needs to develop a marketing strategy that can increase the effectiveness of the price variable. Because by doing so, customer satisfaction or visitors to tourist attractions in the city of Tomohon can be increased.

\subsubsection{THE INFLUENCE OF PLACE VARIABLE $\left(X_{3)}\right.$ ON CUSTOMER SATISFACTION (Y)}

The results of this research, through partial hypothesis testing, prove that the place variable has a strong relationship and a positive influence with the consumer satisfaction variable. The results of testing the hypothesis simultaneously indicate that the place variable together with other marketing mix can affect customer satisfaction. The magnitude of the influence of the Place variable $\left(\mathrm{X}_{3}\right)$ on the Customer Satisfaction variable $(\mathrm{Y})$ is obtained from the value of the Regression Coefficient of 0,218 . This means that if the Place variable $\left(\mathrm{X}_{3)}\right.$ increases (: because the sign is positive) by 1 score, it is expected that the Consumer Satisfaction variable (Y) will increase by 0.218 score, Ceteris Paribus (other factors do not change or remain).

The results above indicate that the place variable has a strong and positive influence relationship with customer satisfaction at tourist attractions in the city of Tomohon. Which this shows that any changes that occur in the Place variable, will also result in changes in Customer Satisfaction in the same direction of change.

Thus, it can be said that every effort made by the company to improve the quality of the place variable will significantly increase the existing customer satisfaction. For that, company management needs to develop a marketing strategy that can encourage the improvement of the quality of the place variable. Because by doing so, it is hoped that consumer satisfaction or visitors to tourist attractions in the city of Tomohon will increase.

\subsubsection{THE EFFECT OF PROMOTION VARIABLES $\left(X_{4)}\right.$ ON CUSTOMER SATISFACTION (Y)}

The results of the research, through partial hypothesis testing, prove that the Promotion variable has a strong relationship and a positive influence with the Consumer Satisfaction variable. The results of testing the hypothesis simultaneously show that the Promotion variable together with other Marketing Mix influences Customer Satisfaction. The magnitude of the influence of the Promotion variable $\left(\mathrm{X}_{4)}\right.$ on the Consumer Satisfaction variable (Y) is obtained from the value of the Regression Coefficient of 0.327 . This means that if the Promotion variable $\left(\mathrm{X}_{4)}\right.$ increases (: because the sign is positive) by 1 score, it is expected that the Consumer Satisfaction variable (Y) will increase by 0.327 scores, Ceteris Paribus (other factors do not change or remain).

The results above indicate that the Promotion variable has a strong and positive influence relationship with Customer Satisfaction at tourist attractions in the city of Tomohon. Which this shows that any changes that occur in the Promotion variable, will also result in changes in Customer Satisfaction in the same direction of change.It can be said that every effort made by the company to improve the quality of the Promotion variable will significantly increase the existing Customer Satisfaction. For that, company management needs to develop a marketing strategy that can encourage increased effectiveness of company promotion. Because by doing so, customer satisfaction or visitors to tourist attractions in the city of Tomohon can be increased. 
Maria V. Tielung, and Victoria N. Untu

\section{CONCLUSIONS AND RECOMMENDATIONS}

\subsection{CONCLUSION}

Based on the results of the discussion, the following conclusions can be drawn:

Analysis with Multiple Linear Regression produces the equation:

$\mathrm{Y}=2.455+0.147 \mathrm{X}_{1}+0.239 \mathrm{X}_{2}+0.218 \mathrm{X}_{3}+0.327 \mathrm{X}_{4}+\mathrm{ei}$

This shows that (according to the order of the regression coefficient): each increase in the Promotion ( $\mathrm{X}_{4)}$, Price $\left(\mathrm{X}_{2)}\right.$, Place $\left(\mathrm{X}_{3)}\right.$, and Product $\left(\mathrm{X}_{1)}\right.$ variables by 1 score, will increase Customer Satisfaction by 0.327 score.

0.239 score; 0.218 score; and 0.147 score, ceterisparibus (other factors are considered or constant). Based on the order of the level of influence, it is concluded that the Promotion variable $\left(\mathrm{X}_{4)}\right.$ has the most dominant influence on customer satisfaction, the next order is the Price variable $\left(\mathrm{X}_{2)}\right.$, then the Place variable $\left(\mathrm{X}_{33}\right.$, then the Product variable $\left(X_{1 \text { ). From }}\right.$ the results of partial hypothesis testing by t test at significance level $(\alpha \square)=0.05$, the value of $t_{\text {count }}$ each independent variable is greater than $t$ table. The conclusion $\mathrm{H}_{0}$ is rejected and $\mathrm{H}_{1}$ accepted, which means that there is a relationship between each variable of marketing mix with consumer satisfaction.

From the results of hypothesis testing simultaneously with the $F$ test at the real level $(\alpha)=0.05$, the calculated $F$ value is greater than the $\mathrm{F}_{\text {table }}$ value. So that $\mathrm{H}_{0 \text { is }}$ rejected and $\mathrm{H}_{1 \text { is }}$ accepted. This shows that the factors are mixed

Marketing simultaneously or together has an influence on consumer satisfaction.

From the analysis results obtained the value of the coefficient of determination ( ${ }^{2}{ }^{2}$ of 0.889 ; which shows that the factors of the Marketing Mix have a contribution or proportion of the contribution to the variation (fluctuation) of Consumer Satisfaction by $88.9 \%$, while the remaining $11.1 \%$ is explained by other factors.

From the research results, the value of the Correlation Coefficient (r) is $0.943(94.3 \%)$ or close to $1(100 \%)$, which indicates that there is a very close and positive relationship between the Marketing Mix variables and the Consumer Satisfaction

\subsection{SUGGESTIONS}

The things that can be suggested in connection with the research results are as follows:

Basically, tourist attractions in Tomohon City have implemented good marketing strategies, especially those related to the Marketing Mix, so that they are known by the community and have many visitors. However, given the increasing intelligence and tastes of consumers, it is advisable for companies to continue to evaluate the Marketing Mix strategy in order to retain consumers / customers.

By looking at the rapid development of tourism businesses in the Tomohon area, as well as the determination as a world tourism city in the Year 2021 as well as the organizer of the TIFF (Tomohon International Flower Festival) next year, tourist attractions in Tomohon City must anticipate and prepare themselves. Among other things, by fixing the Marketing Mix strategy, in order to further increase Customer Satisfaction.

Given that the Marketing Mix aspect is not the only factor that can affect Customer Satisfaction, management at tourist attractions in Tomohon City should synchronize this with other policies in increasing Customer Satisfaction. Which in turn can retain existing customers or even add new customers, so as to increase the profit achieved by the company.

\section{SOURCES OF FUNDING}

This research received no specific grant from any funding agency in the public, commercial, or not-for-profit sectors.

\section{CONFLICT OF INTEREST}

The author have declared that no competing interests exist. 


\section{ACKNOWLEDGMENT}

This research was funded by the Ministry of Education and Culture. All research teams contributed directly to the completion of this research. Therefore, the authors thank you for the help and motivation that has been given.

\section{REFERENCES}

[1] Aker and Umar (2011), "Marketing Management”, Erlangga Publisher, Jakarta.

[2] Assauri Sofyan, (2010), " Marketing Management; Basic Concepts and Strategies",Rajawali Press Publisher, Jakarta.

[3] Boyd, Harper W, Walker O, C and Lurrenche, Jea n-Claude (2010), " Marketing Management: A Strategic Approach with Oriental Global ", Second Edition Erlangga, Jakarta.

[4] Kotler, Philip (2012), " Marketing Management, Planning Analysis, Control ", Prentice Hall, Indonesian Edition, Jakarta: Salemba 4.

[5] (2011, Marketing Management, The Millenium Edition”, Prentice Hall Inc, New Jersey.

[6] Kotler, Philip and Sidney (2012), “Expanding Marketing Concepts - Marketing Classic, Revised Edition”, Amara Books, Yogyakarta.

[7] Lincoln Arsyad (2010), " Sampling Methods ", Erlangga Publisher, Jakarta.

[8] Neil H. Borden (2011), "Marketing Classic, Revised Edition", Amara Books, Yogyakarta.

[9] Phlip Kotler and Sidney J. Levy (2012), " Expanding Marketing Concepts, Classic Marketing, Revised Edition ", Amara Books, Yogyakarta.

[10] Rangkun (2011), " Measuring Methods of Respondent Variables “, Salemba 4, Jakarta.

[11] Suliyanto (2010), " Business and Marketing Research Methodology ", Ghalia Indonesia, Jakarta.

[12] Soemarsono (2014), " Business Research Methods ", Publisher PT. Alphabet, Bandung.

[13] Supranto (2010), " Hypothesis Testing Procedure ", Erlangga, Jakarta.

[14] Theodore Levitt (2007), "Marketing Classic, Marketing Myopia, Revised Edition",Amara Books, Yogyakarta.

[15] Walker and Larreche (2010), "Corporate Marketing Strategy", Salemba 4, Jakarta. 